\title{
POLA SINGKATAN KATA DAN GENDER
}

\section{ABBREVIATION PATTERN AND GENDER}

\author{
${ }^{1}$ Lenny Nofriyani Adam, ${ }^{2}$ Rince Jalla Wabang \\ ${ }^{1,2}$ Universitas Timor \\ ${ }^{1}$ lennyadam@unimor.ac.id, ${ }^{2}$ rincejalla@unimor.ac.id
}

\begin{abstract}
Abstrak
Perbedaan gender dalam penggunaan bahasa selalu ditekankan dalam penelitian-penelitian tentang bahasa dan gender. Ada begitu banyak penelitian yang mengklaim perbedaan karakteristik gaya berbahasa yang disortir oleh konstruksi sosial yang satu ini. Penelitian ini mengkaji singkatan kata yang digunakan oleh laki-laki dan perempuan. Tujuannya untuk mendeskripsikan perbedaan pola singkatan kata yang digunakan oleh laki-laki dan perempuan dalam percakapan di grup whatsapp. Penelitian ini berlandaskan pada teori Lakoff yang menyatakan bahwa laki-laki dan perempuan memiliki variasi morfologi yang berbeda dalam menggunakan bahasa. Hasil penelitian memperlihatkan adanya perbedaan pola singkatan kata yang digunakan oleh laki-laki dengan pola singkatan kata yang digunakan oleh perempuan dalam sebuah percakapan. Laki - laki lebih cenderung menggunakan kontraksi dan apokop sedangkan perempuan lebih sering menggunakan pola sinkop dan afaresis. Namun hal yang menarik adalah keduanya melibatkan pola yang berhubungan dengan angka dalam percakapan.
\end{abstract}

Kata kunci: pola singkatan kata, gender, variasi morfologi.

\begin{abstract}
Gender difference in language use is always emphasized in any study of language and gender.Various different characteristics between men and women in using language are explained in many researchs on the diversity of language sorted by this social construction. This study examines the abbreviations used by men and woman in a conversation. The objective is to describe the distinctive patterns of abbreviations used by women and men on the conversation in a WhatsApp group. This study based on the theory from Lakoff which implies that women and men have different morphological variation in using language. The result of the finding analysis shows that there is a difference in the abbreviation patterns used by the men and women in the conversation. Men tend to use constractions and apocope. On the other hand, women tend to use abbreviation patterns of syncope and afaresis. In addition, both of women and men are involving number pattern in the conversation.
\end{abstract}

Keywords: abbreviation pattern, gender, morphological variation

\section{PENDAHULUAN}

Penelitian tentang keragaman bahasa laki-laki dan perempuan selalu mengungkapkan fakta baru adanya perbedaan karakteristik di antara keduanya dalam menggunakan bahasa. Gagasan bahwa laki-laki dan perempuan menggunakan bahasa secara berbeda inilah yang selalu ditekankan atau menjadi fokus kajian dalam penelitian tentang bahasa dan gender. Ada begitu banyak penelitian yang mengklaim perbedaan gaya berbahasa yang disortir dengan konstruksi sosial yang satu ini.

Ronald Wardaugh menyatakan “ Gender is a key component of identity” (Meyerhoff, 2006). Gender dijadikan faktor pembeda untuk melihat cara dan gaya berbahasa yang akhirnya melahirkan istilah bahasa laki-laki dan bahasa perempuan. Kedua istilah ini menyiratkan 
bahwa laki-laki dan perempuan memang memiliki kekhasan tersendiri dalam berbahasa. Dalam bukunya, Wardaugh menyebutkan para perintis yang mengkaji dan memaparkan sejumlah penelitian bahwa perempuan dan laki-laki menggunakan bahasa dengan cara yang berbeda. Dikatakan bahwa bahasa perempuan dinilai lebih halus dan sopan, lebih bervariasi, lebih formal, lebih kompleks, namun dianggap tidak tegas, tidak secara terang-terangan karena sering menggunakan kata-kata kiasan yang nyatanya jarang digunakan laki-laki. Lain halnya dengan bahasa perempuan, bahasa laki-laki dinilai kurang sopan, kurang bervariasi, kurwaang formal, namun tegas dan lebih sederhana karena laki-laki suka berbicara terangterangan akan sesuatu.

Hal senada menjadi bahan utama kajian Robin Lakoff, linguis yang mempelopori penelitian yang memusatkan kajiannya pada hubungan antara bahasa dan gender. Ia mengemukakan bahwa fitur-fitur bahasa yang digunakan oleh laki-laki dan perempuan itu berbeda. Dalam Bukunya Language and Women's Place (1975), ia menyatakan bahwa dalam bidang morfologi, perempuan sering sekali menggunakan kata-kata yang berhubungan dengan warna yang spesifik seperti mauve, beige, aquamarine, dan lavender yang jarang digunakan oleh laki-laki. Ini merupakan variasi morfologi yang digunakan secara berbeda oleh laki-laki dan perempuan (Llamas, 2007).

Variasi morfologi yang digunakan oleh laki-laki dan perempuan menjadi perhatian dalam penelitian ini. Penulis menginvestigasi variasi morfologi yang digunakan oleh laki-laki dan perempuan dalam percakapan lewat pola singkatan yang digunakan. Dalam percakapan seringkali kita menggunakan singkatan kata yang merupakan hasil dari proses pemendekan kata. Dalam penelitian ini penulis memfokuskan kajian pada pola singkatan yang digunakan laki-laki dan pola singkatan yang digunakan perempuan. Dalam penelitian ini penulis membatasi cakupan penelitiannya pada pola singkatan kata yang digunakan oleh laki-laki dan perempuan dalam percakapan di sebuah grup whatsapp.

Francis Katamba menjelaskan dalam Bukunya, the most productive ways of word-formation are affixation, conversion, word composition, shortening (abbreviation, acronym, clipping, blending), and also other ways such as : backformation, postpositivation of words, sound imitation, repetition, lexical-semantic wordformation, reduplication, creative respelling, errors, etc (Katamba, 2006). Salah satu cara pembentukan kata yang paling produktif adalah proses pemendekan kata (shortening). Singkatan kata yang adalah hasil proses pemendekan kata sering digunakan dalam percakapan. Penelitian ini bertujuan untuk melihat dan mendeskripsikan perbedaan pola singkatan kata yang digunakan oleh laki-laki dengan pola singkatan kata yang digunakan oleh perempuan dalam percakapan.

Singkatan kata dikatakan sebagai produk dari proses pemendekan kata atau frasa karena singkatan dibentuk dari bagian-bagian yang diambil dari kata atau frasa yang dipendekkan tersebut dengan pertimbangan bahwa bentuk singkatan kata yang dihasilkan tetap membawa makna yang sama dengan kata atau frasa aslinya. Misalnya dalam bahasa Inggris singkatan BBC merupakan kependekan dari British Broadcasting Corporation dan UNESCO dari United Nations Educational, Scientific and Cultural Organization, dan UPI merupakan singkatan dari Universitas Pendidikan Indonesia. Singkatan kata biasa digunakan dalam percakapan karena dinilai lebih cepat dan mudah untuk ditulis untuk menyampaikan tujuan pengguna dalam percakapan.

Pola singkatan kata dapat dibedakan dengan beberapa cara, yakni pengurangan morfem seperti dalam contoh Doktor menjadi Dok atau Profesor menjadi Prof; mengambil setiap huruf awal setiap kata seperti dalam kata HIV yang merupakan singkatan dari Human Immunodeficiency Virus atau kombinasi huruf awal kata pertama dan keseluruhan kata yang tersisa seperti dalam contoh V-day untuk valentine day dan B-day untuk Birthday. 
Umumnya banyak singkatan kata yang dibentuk dengan mengambil huruf awal dari kata, frasa atau runtutan kata untuk membentuk suatu kata baru namun terkadang singkatan kata juga dibentuk dengan penghilangan morfem entah itu penghilangan dari bagian awal, tengah maupun akhir kata atau frasa yang disingkat.

Tarigan (1995) menjelaskan tiga cara penyingkatan kata yakni Penghilangan fonem, kontraksi dan akronim. Berdasarkan tempat fonem tersebut dihilangkan, cara pembentukan singkatan yang pertama, dengan penghilangan fonem, dibedakan lagi menjadi tiga jenis, yakni Afaresis, Sinkop dan Apokop. Afaresis adalah proses penghilangan fonem pada bagian awal kata tanpa adanya perubahan dalam makna. Dengan kata lain, baik bentuk semula maupun bentuk sesudah penghilangan atau penanggalan fonem tersebut tetap mempunyai makna yang sama, sehingga perubahan bentuk tidak mengakibatkan perubahan pada makna kata. Contohnya : kata tetapi menjadi tapi, besok menjadi esok, ibunda menjadi bunda dan contoh dalam bahasa Inggris defend menjadi fend. Kemudian sinkop merupakan proses penghilangan atau penanggalan fonem dari bagian tengah kata tanpa merubah makna kata, misalnya bahasa menjadi basa, tahu menjadi tau, bakso menjadi baso. Lalu yang terakhir ada Apokop yakni proses penghilangan atau penanggalan fonem yang terjadi pada akhir kata tanpa mengakibatkan perubahan pada makna kata tersebut. Misalnya : Bapak menjadi bapa, kasih menjadi kasi, dan abah menjadi aba. Dari penjelasan yang dikemukakan oleh Tarigan tentang tiga jenis pola penanggalan atau penanggalan fonem, terlihat bahwa kedudukan fonem yang ditanggalkan dapat terjadi di awal, di tengah dan di akhir kata. Fonem yang ditanggalkan atau dihilangkan tersebut dapat berupa huruf vokal maupun konsonan.

Cara pembentukan yang kedua yaitu Kontraksi. Kontraksi adalah penyingkatan, penyusutan, atau penciutan fonem dalam kata atau frasa, tanpa mengakibatkan perubahan makna kata atau frasa tersebut. Contoh kontraksi dalam bahasa Indonesia : tidak ada menjadi tiada, bagai itu menjadi begitu. Dalam Bahasa Inggris kita sering menemukan kontraksi dalam bentuk penghilangan vokal (biasanya digantikan dengan tanda kutip) seperti dalam kata I'm merupakan bentuk kontraksi dari I am, won't dari "will not" dan ain't untuk "am not".

Cara pembentukan yang ketiga yaitu Akronim yang merupakan singkatan yang dibentuk dengan cara mengambil setiap huruf awal, kadang juga suku kata awal kata atau frasa yang mau disingkat dan dapat dibaca atau dilafalkan sebagai sebuah kata. Adakalanya suatu akronim menjadi kata yang diterima oleh masyarakat penutur, bahkan tidak jarang suatu akronim lebih dikenal daripada kata-kata yang merupakan bentuk asal atau kepanjangan dari kata itu sendiri seperti Rudal yang merupakan kepanjangan dari peluru kendali. Contoh akronim seperti polwan merupakan kepanjangan dari polisi wanita, Universitas Pendidikan Indonesia menjadi UPI. Dalam bahasa Inggris seperti Radio Detection And Ranging menjadi radar ; United Nations Educational, Scientific and Cultural Organization menjadi UNESCO dan North Atlantic Treaty Organization menjadi NATO.

Sejalan dengan Tarigan, Kridalaksana (2001:162) mendefinisikan akronim sebagai proses pemendekan yang menggabungkan huruf atau suku kata atau bagian lain yang ditulis dan dilafalkan sebagai sebuah kata, yang setidak-tidaknya memenuhi fonotaktik bahasa tersebut. Contohnya dalam kata FKIP / fkip/ bukan /ef/, /ka/, /i/, /pe/; ABRI /fkip/ bukan /a/, /b/, /r/, /i/; UPI /upi/ bukan /u/, /pe/, /i/.

Penelitian tentang singkatan kata sebagai hasil pemendekan kata telah dilakukan sejak 
dahulu. Salah satu penelitian dilakukan oleh J. de Vries pada tahun 1963 tentang Indonesian abbreviations and acronyms yang memberikan banyak contoh singkatan-singkatan kata pada jaman itu. Penelitian yang menggunakan media pengumpulan data dan cara analis yang sama juga pernah dilakukan oleh Lydia Irawati pada tahun 2007 dengan judul makalah : Singkatan dan Akronim dalam media chatting namun semuanya tidak memasukan gender sebagai kategori pembeda dalam penggunaan pola singkatan kata.

\section{METODE PENELITIAN}

Penelitian ini merupakan penelitian awal (initial project) yang dilakukan menggunakan kombinasi pendekatan kuantitatif dan kualitatif deskriptif. Data dalam penelitian ini berupa 50 singkatan kata yang digunakan oleh laki-laki dan 50 singkatan kata yang digunakan oleh perempuan yang dikumpulkan dari percakapan sebuah grup di whatsapp. Terdapat tiga tahap yang dilakukan dalam menganalisis data tersebut. Yang pertama yaitu mengidentifikasi singkatan yang digunakan baik itu oleh laki-laki maupun perempuan. Tahap kedua adalah mengkategorikan singkatan-singkatan tersebut berdasarkan pola-pola pembentukannya. Tahap terakhir yakni menghitung frekuensi kemunculan masing-masing pola singkatan kata dan menentukan kecenderungan pola singkatan kata yang digunakan oleh laki-laki dan juga perempuan dalam sebuah percakapan.

\section{HASIL DAN PEMBAHASAN}

\section{Pola Singkatan Kata yang digunakan Laki-laki}

Data penelitian ini mencakup 50 kosakata singkatan yang digunakan oleh laki - laki dan 50 kosakata singkatan yang digunakan oleh perempuan dalam percakapan di grup.

Tabel 1. Contoh temuan singkatan yang digunakan oleh kaum laki - laki.

\begin{tabular}{|c|c|c|}
\hline Singkatan Kata & Bentuk Asal & Pola Singkatan \\
\hline B & Beta & Apokop \\
\hline Ok & Oke & Apokop \\
\hline Sbb & Sori baru balas & Akronim \\
\hline Dengan & Dengan & Sinkop \\
\hline D & Di & Apokop \\
\hline Bjlan & Bajalan & Sinkop \\
\hline Sbnarny & Sebenarnya & Apokop \\
\hline Tidak & Tidak & Kontraksi \\
\hline Da & Ada & Afaresis \\
\hline Smansa & $\begin{array}{l}\text { Sekolah Menengah Atas } \\
\text { Negeri Satu }\end{array}$ & Kontraksi \\
\hline
\end{tabular}

Dari 50 data kosakata singkatan yang digunakan oleh laki - laki terdapat beberapa kategori pola penyingkatan yang muncul, yakni 1) Pola Afaresis 6 kosakata (12\%); 2) Pola Sinkop 9 kosakata (18\%); 3) Pola Apokop 11 kosakata(22\%); 4) Pola Kontraksi 20 kosakata(40\%); 5) Ada pola lainnya berupa angka dengan total kemunculan 4 kosakata (8\%). 
1) Pola Afaresis

Kosakata yang termasuk ke dalam pola Afaresis adalah kosakata singkatan yang dibentuk melalui proses penghilangan fonem pada awal kata tanpa adanya perubahan dalam makna. Dengan kata lain, baik bentuk semula maupun bentuk sesudah penghilangan atau penanggalan fonem tersebut tetap memiliki makna yang sama, sehingga perubahan bentuk tersebut tidak mengakibatkan perubahan makna kata.

$\begin{array}{ll}\text { Bentuk asal kata } & \text { Hasil Pemendekan } \\ \text { Ada } & \mathrm{Da} \\ \text { Itu } & \text { Tu } \\ \text { Mengantuk } & \text { Ngantuk }\end{array}$

*Pada proses pemendekan di atas, singkatan kata dihasilkan dengan cara menghilangkan fonem pada bagian awal kata asli.

2) Pola Sinkop

Yang termasuk pola Sinkop adalah kosakata singkatan yang dibentuk melalui proses penghilangan atau penanggalan fonem di bagian tengah kata asal tanpa merubah makna kata, misalnya dalam temuan kata dengan menjadi dngan, sembub menjadi smbuh, dulu menjadi $d l u$.

\begin{tabular}{ll} 
Bentuk asal kata & Hasil Pemendekan \\
\cline { 1 - 2 } Dengan & Dgn \\
Sembuh & Smbuh \\
Dulu & Dlu
\end{tabular}

*Singkatan kata yang dihasilkan dari proses pemendekan di atas dilakukan dengan cara menghilangkan fonem pada bagian tengah kata asli.

3) Pola Apokop

Untuk kosakata yang termasuk dalam pola Apokop adalah kosakata singkatan yang dibentuk melalui proses penghilangan atau penanggalan fonem yang terjadi pada akhir kata tanpa mengakibatkan perubahan makna kata tersebut.

$\begin{array}{ll}\text { Bentuk asal kata } & \text { Hasil Pemendekan } \\ \text { sudah } & \text { su } \\ \text { kakak } & \mathrm{ka} \\ \text { sudah } & \text { su }\end{array}$

${ }^{*}$ Proses pemendekan di atas, singkatan kata dihasilkan dengan cara menghilangkan fonem pada akhir kata.

4) Pola kontraksi

Laki - laki sering sekali menggunakan Kontraksi yakni kosakata singkatan yang dibentuk melalui proses penyingkatan, penyusutan, atau penciutan fonem dalam kata dan tetap tanpa merubah makna kata aslinya.
Bentuk asal kata
Hasil Pemendekan
Di mana
dimn 


$\begin{array}{ll}\text { Tidak bisa } & \text { tdkbs } \\ \text { Juga } & \text { jg } \\ \text { Mana } & \text { mn }\end{array}$

*Pada proses pemendekan di atas, singkatan kata dihasilkan dengan cara menyingkat atau menciutkan fonem dari kata yang disingkat.

5) Pola lain

Dalam analisis penelitian ini juga ditemukan juga kosakata singkatan yang melibatkan angka.

$\begin{array}{ll}\text { Bentuk asal kata } & \text { Hasil Pemendekan } \\ \text { Kapan-kapan } & \text { kapan2 } \\ \text { Kakak } & \text { ka2 } \\ \text { tidak apa-apa } & \text { tdkap2 }\end{array}$

${ }^{*}$ Pada proses pemendekan di atas, singkatan kata dihasilkan dengan cara menggantikan kata yang diulang dengan angka.

\section{Pola Singkatan Kata yang digunakan Perempuan}

Tabel 2. Contoh Temuan singkatan yang digunakan oleh Perempuan.

\begin{tabular}{lll}
\hline Singkatan Kata & Bentuk asal & Pola Singkatan \\
\hline Gimana & Bagaimana & Afaresis \\
\hline Spa & Siapa & Sinkop \\
\hline Kmar & Kamar & Sinkop \\
\hline Ntar & Sebentar & Afaresis \\
\hline Sond & Sonde (tidak) & Apokop \\
\hline Sbuk & Sibuk & Sinkop \\
\hline Bt & Beta & Sinkop \\
\hline Pikir2 & Pikir - pikir & Nomor \\
\hline Snde & Sonde & Sinkop \\
\hline Blm & Belum & Sinkop \\
\hline
\end{tabular}

Dari data 50 singkatan yang digunakan oleh Perempuan terdapat beberapa kategori pola penyingkatan yang muncul, yakni 1) Pola Afaresis muncul 11 kosakata (22\%); 2) Pola Sinkop muncul 25 kosakata (50\%); 3) Pola Apokop muncul 6 kosakata (12\%); 4) Pola kontraksi muncul 4 kosakata (8\%). 5) Pola lainnya berupa pola yang melibatkan angka dengan total kemunculan 2 kosakata (4\%) dan bahasa asing dengan total kemunculan 2 kosakata (4\%).

1) Pola Afaresis

Kosakata yang termasuk pola afaresis adalah kosakata singkatan yang proses penghilangan fonemnya terjadi pada awal kata tanpa adanya perubahan dalam makna. Dengan kata lain, baik bentuk semula maupun bentuk sesudah penghilangan atau 
penanggalan fonem tersebut tetap mempunyai makna yang sama, sehingga perubahan bentuk tidak mengakibatkan perubahan makna kata.

\begin{tabular}{ll} 
Bentuk asal kata & Hasil Pemendekan \\
\hline Sebentar & ntar \\
Gimana & gmn \\
Kawan & kwan
\end{tabular}

*Pada proses pemendekan di atas, singkatan kata dihasilkan dengan cara menghilangkan fonem pada bagian awal kata asli.

2) Pola Sinkop

Singkatan kata yang termasuk pola sinkop adalah kosakata singkatan yang proses penghilangan atau penanggalan fonemnya terjadi di bagian tengah kata tanpa merubah makna kata.

$\begin{array}{ll}\text { Bentuk asal kata } & \text { Hasil Pemendekan } \\ \text { Penting } & \text { pentng } \\ \text { Berarti } & \text { brrti } \\ \text { Berapa } & \text { brpa }\end{array}$

*Pada proses pemendekan di atas, singkatan kata dihasilkan dengan cara menghilangkan fonem pada bagian tengah kata asli.

3) Pola Apokop

Singkatan kata yang termasuk pola apokop adalah kosakata singkatan yang proses penghilangan atau penanggalan fonem yang terjadi pada akhir kata tanpa mengakibatkan perubahan makna kata tersebut.

\begin{tabular}{ll} 
Bentuk asal kata & Hasil Pemendekan \\
\hline Punya & pu \\
Nomor & no \\
Punya & pu \\
Ada & da
\end{tabular}

*Pada proses pemendekan di atas, singkatan kata dihasilkan dengan cara menghilangkan fonem pada bagian akhir kata asli.

4) Pola Kontraksi

Pola yang juga muncul yaitu kosakata yang termasuk kontraksi, yakni kosakata singkatan yang dibentuk melalui proses penyingkatan, penyusutan, atau penciutan fonem dalam kata, tanpa perubahan makna kata.

$\begin{array}{ll}\text { Bentuk asal kata } & \text { Hasil Pemendekan } \\ \text { Bagai itu } & \text { begitu } \\ \text { Menginap } & \text { nginap }\end{array}$

*Pada proses pemendekan di atas, singkatan kata dihasilkan dengan cara penyusutan, atau penciutan fonem. 
5) Pola lain

Dalam analisis pola singkatan yang digunakan oleh perempuan ini ditemukan juga kosakata penyingkatan yang melibatkan angka, contohnya pikir - pikir menjadi pikir2, kumpul - kumpul menjadi kumpul2 dan istilah asing .

$\begin{array}{ll}\text { Bentuk asal kata } & \text { Hasil Pemendekan } \\ \text { Get Well Soon } & \text { GWS } \\ \text { Correct Me If I Wrong } & \text { CMIIW } \\ \text { Bentuk asal kata } & \underline{\text { Hasil Pemendekan }} \\ \text { Pikir-pikir } & \text { pikir2 } \\ \text { Kumpul-kumpul } & \text { Kumpul2 }\end{array}$

\section{SIMPULAN}

Berdasarkan temuan dan pembahasan mengenai pola singkatan kata dan gender dapat disimpulkan bahwa ada perbedaan pola singkatan yang digunakan oleh laki - laki dan perempuan dalam percakapan di whatsapp. Dari data yang ditemukan, Laki - laki cenderung menggunakan pola Kontraksi 40\% dan pola apokop 22\% sedangkan perempuan lebih sering menggunakan pola Sinkop 50\% dan pola Afaresis $22 \%$.

Hal yang menarik di sini adalah dalam percakapan baik itu laki-laki maupun perempuan, sama-sama menggunakan pola singkatan yang melibatkan angka dan juga istilah asing.

\section{DAFTAR PUSTAKA}

Bakaradze, Ekaterine. (2016). The Study Of English Language Vocabulary Development Through Shortened Words And Units. International Journal of Arts \& Sciences, ISSN: 1944-6934: 09(02):419-434.

Chaer, Abdul. (1983). Linguistik Suatu Pengantar. Bandung: Angkasa.

Gelb, I. J, A. Study of writing, Revised Edition, Chicago: http:// / oi.uchicago.edu

H. P. Ahmad. (2012). Linguistik Umum. Jakarta: Erlangga.

Irawati, Lydia. (2007). Singkatan dan Akronim dalam media chatting. http://sahaka.multiply.com J. de Vries, Indonesian abbreviations and acronyms. In: Bijdragen tot de Taal-, Land- en Volkenkunde 126 (1970), no: 3, Leiden, 338-346 available in http://www.kitlvjournals.nl

Katamba, F. and Jhon Stonham. (2006). Modern Linguistics : Morphology, $2^{\text {nd }}$ edition. New York: Palgrave Macmillan.

Kridalaksana, Harimurti. (2001). Kamus Linguistik. Jakarta: Gramedia Pustaka Utama

Litosseliti, Lia. (2010). Research Methods in Linguistics. New York: Continuum International 1 Punblishing Group.

Llamas, C., Mullany, L. \& Stockwell, P. (2007). The Routledge Companion to Sociolinguistics , $2^{\text {nd }}$ edition.

London: Routledge. 
Meyerhoff, Miriam. (2006). Introducing Sociolinguistics, 1st pub. New York: Routledge.

Probowati, Dian. (2008). Pola - Pola Pembentukan Singkatan. Jakarta: Unpublish Thesis Fakultas Ilmu Budaya Universitas Indonesia.

Tarigan, Henry Guntur. (1995). Pengajaran Morfologi. Bandung: Angkasa.

(1995). Pengajaran Semantik. Bandung: Angkasa.

Wardhaugh, Ronald. (2006). An Introduction to Sociolinguistics, New York: Basil Blackwell Inc. Suryabrata, Sumadi. 2002. Metodologi Penelitian. Jakarta: PT. Raja Grafindo Persada.

Verhaar, J.W.M. 1996. Asas-asas Linguistik. Yogyakarta: Gadjah Mada University Press. 